\title{
Genetics of gynodioecy in Hawaiian Bidens (Asteraceae)
}

\author{
M. Sun*
}

Department of Botany, University of British Columbia, Vancouver, Canada, V6T 2B1.

Inheritance of male sterility in all gynodioecious species of Hawaiian Bidens was investigated by experimental crosses conducted in greenhouses. Both male-sterile individuals and hermaphrodites were segregated in the progenies of openpollinated female and hermaphroditic plants growing in nature. The ratios $(\mathrm{H}: \mathrm{MS})$ of $1: 0,1: 1,3: 1$ were observed in the $\mathrm{F} 1$ generations; $3: 1$ and $15: 1$ in the $\mathrm{F} 2$ generations; and $1: 1$ and $3: 1$ in the backcrosses. Thirteen interspecific triple crosses and all quadruple crosses gave MS progenies, indicating a directly allelic relationship among male sterility genes in all gynodioecious species. Based on these results, A digenic-cytoplasmic model was proposed, and the evolution of gynodioecy in Hawaiian Bidens was discussed.

\section{INTRODUCTION}

Gynodioecy is the occurrence of male-sterile individuals in an otherwise hermaphrodite population in plants. The genetic basis of male sterility in many crop mutants has been investigated (see Gottschalk and Kaul, 1974 for a review), but not much is known of the inheritance of male sterility in natural gynodiocious species. The study of genetic mechanism of male sterility is important in understanding the maintenance of females in natural populations and the evolution of gynodioecy as a rare breeding system. To date, inheritance of male sterility has been studied for only about 12 natural gynodioecious species (see Ross, 1978, and Charlesworth, 1981 for reviews). The results of these studies indicate that the inheritance of male sterility in wild species is more complicated than simple single-factor nuclear or cytoplasmic control. In most of the species studied, the genetic mechanism of male sterility remains unclear.

Of 27 taxa of Bidens endemic to the Hawaiian Isands, 13 are gynodioecious. These taxa provide excellent materials for studying the genetics of gynodioecy. The comparative studies of microsporogenesis in nine gynodioecious taxa of Hawaiian Bidens show that the early abnormal

* Present address: Department of Forest Science, University of Alberta, Edmonton, Alberta, Canada, T6G 2H1. vacuolation of the tapetum causes premeiotic degeneration of microspore mother cells, resulting in complete male sterility in the females (Sun, 1986; Sun and Ganders, 1987). The homogeneous developmental expression of male sterility in these materials suggest a common genetic mechanism in all gynodioecious species. In this paper, I report the results of genetic studies of gynodioecy in Hawaiian Bidens.

\section{MATERIALS AND METHODS}

Seeds and cuttings of Hawaiian species of Bidens were collected and raised to flowering plants in greenhouses. These plants included hermaphrodites and females, and served as the parental generation for many experimental crosses. All the crosses were made by hand in greenhouses. Flowers were protected from pollinator contamination by placing the plants into insect-proof growth chambers or cages. Most crosses made were between females and hermaphrodites by simply rubbing hermaphrodite flower heads with copious pollen grains onto the female flower heads at the optimum receptive phase. Selfing of hermaphrodites was performed by rubbing flower heads on the same plant together. In a few cases where hermaphrodite plants were used as maternal parents, the pollen grains were blown away from 
the flower heads before the stigmas were receptive. Strong protandry in the Hawaiian species of Bidens efficiently prevents self-fertilisation. No attempt was made to emasculate the flowers since all disc flowers are very small.

Male sterility could be easily identified in the $F 1$ and $F 2$ progeny, and in the progenies of backcrosses and triple-crosses. Male-sterile plants were recognised on the basis of flower and anther morphology. Male-sterile flowers commonly have smaller flower size and lighter anther colour than hermaphroditic flowers. In addition, male-sterile anthers are small, indehiscent, and shrivelled in appearance (fig. 1). In cases of uncertainty, the flower heads were checked under a microscope for the presence or absence of pollen grains. There is no intermediate form of male sterility among flowers within plants or among plants, so that phenotypes can be classified unambiguously.

The inheritance of male sterility in all gynodioecious species was studied using F1, F2, and backcross generations. Triple-crosses and quadruple-crosses were performed to test allelism among gynodioecious species. Further details of the crossing designs can be seen in Tables 6 and 7. The segregation ratios of females and hermaphrodites were recorded from naturally pollinated hermaphrodites and females from populations of $B$. forbesii subsp. forbesii, $B$. populifolia, and $B$. sandvicensis subsp. sandvicensis. Seeds of these populations were collected in the field, and grown in a greenhouse.

\section{RESULTS}

Segregations of hermaphrodites and females in progeny grown from seeds collected from four natural populations are given in table 1. Both

Table 1 Segregation of females and hermaphrodites in 4 gynodioecious populations raised in a greenhouse

\begin{tabular}{llll}
\hline & & \multicolumn{2}{l}{ No. of progeny } \\
\cline { 3 - 4 } Species & $\begin{array}{l}\text { Maternal } \\
\text { sex type* }\end{array}$ & H & MS \\
\hline B. forbesii & & & \\
FORB F1 & H & 18 & 2 \\
FORB F2 & MS & 13 & 3 \\
& H & 29 & 8 \\
B. populifolia & HS & 29 & 9 \\
B. sandvicensis & H & 18 & 2 \\
& MS & 28 & 5 \\
& & 43 & 9 \\
\hline
\end{tabular}

${ }^{*} \mathrm{H}$ : hermaphrodites; MS: male steriles.

female and hermaphroditic maternal plants in natural populations of these gynodioecious species produced hermaphrodite and female progeny. Table 2 presents the segregation ratios in F1 progeny for 27 experimental crosses between females of all gynodioecious species of Hawaiian Bidens and hermaphrodites of non-gynodioecious species. The results are homogeneous. All F1 plants were hermaphrodites, indicating that the hermaphrodite condition is dominant to the male-sterile. The

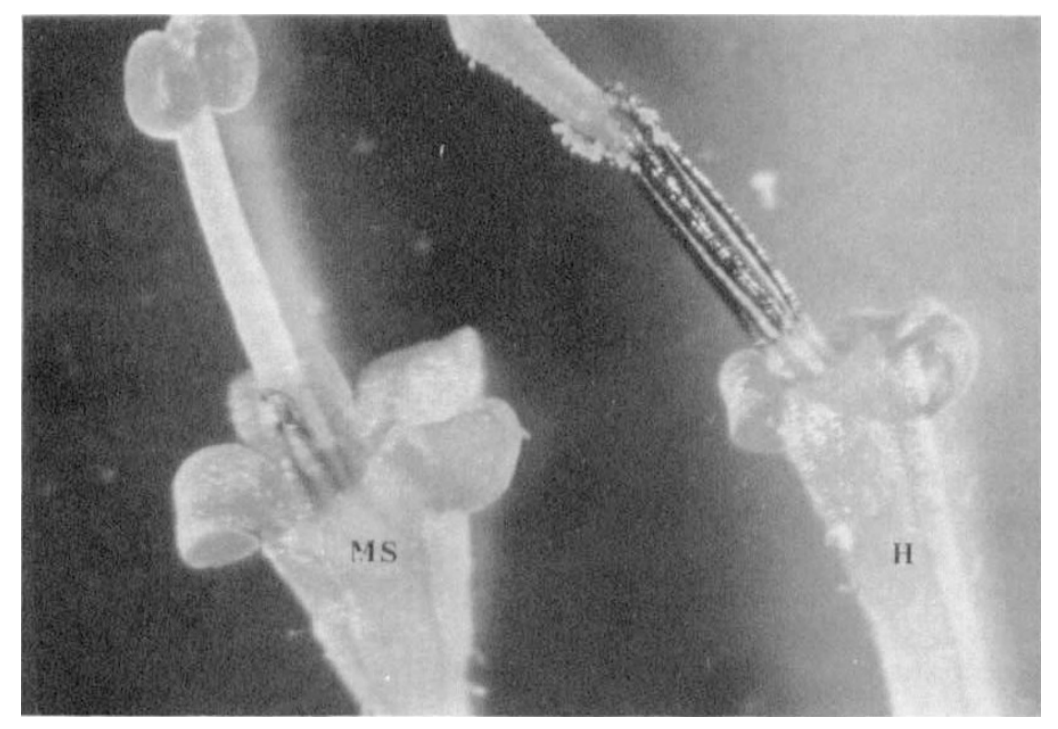

Figure 1 Male-sterile disk flower (MS) and hermaphroditic disk flower (H) in gynodioecious species of Hawaiian Bidens. 
Table 2 Segregation in the F1 generation in experimental crosses between females of gynodioecious species and hermaphrodites of non-gynodioecious species. All malesterile plants have the same genotype: mmnn, and all hermaphrodites have the same genotype: MMNN. The empty ( ) designates that cytoplasm can be either type: (A) or (B). The $\mathrm{N}$ locus has no effect in (A) cytoplasm (Genotype assignments in all tables are based on the genic-cytoplasmic model, as discussed in the text)

\begin{tabular}{|c|c|c|}
\hline \multirow[b]{2}{*}{ Experimental cross } & \multicolumn{2}{|c|}{ No. of F1 progeny* } \\
\hline & $\mathrm{H}$ & MS \\
\hline MS ( )mmnn $\times$ H ( )MMNN & & \\
\hline B. cervicata $(8 \mathrm{~B}) \times B$. campylotheca $(114 \mathrm{~A})$ & 4 & 0 \\
\hline$\times B$. cosmoides $(9)$ & 8 & 0 \\
\hline$\times B$. hillebrandiana $(68 \mathrm{~B})$ & 2 & 0 \\
\hline B. forbesii $(12 \mathrm{~A}) \times B$. cosmoides $(9)$ & 5 & 0 \\
\hline$\times B$. hillebrandiana $(68 \mathrm{~B})$ & 2 & 0 \\
\hline$\times$ B. mauiensis $(10 \mathrm{~B})$ & 6 & 0 \\
\hline$\times$ B. molokaiensis $(11)$ & 6 & 0 \\
\hline$\times$ B. valida $(131 \mathrm{~A})$ & 6 & 0 \\
\hline B. hawaiensis $(51 \mathrm{~A}) \times B$. mauiensis $(10 \mathrm{~A})$ & 6 & 0 \\
\hline$\times$ B. molokaiensis $(11 \& 72 \mathrm{~A})$ & 9 & 0 \\
\hline B. menziesii $(30 \& 84) \times B$. mauiensis & 4 & 0 \\
\hline$\times$ B. campylotheca $(114 \mathrm{~A})$ & 4 & 0 \\
\hline$\times \# 179 \mathrm{~B}$ & 3 & 0 \\
\hline B. micrantha $(133 \mathrm{~A}) \times B$. campylotheca $(195 \mathrm{C} \& 114 \mathrm{~A})$ & 8 & 0 \\
\hline$\times B$ valida $(131 \mathrm{~A})$ & 5 & 0 \\
\hline B. populifolia $(42 \mathrm{~B}) \times$ B. cosmoides $(9)$ & 16 & 0 \\
\hline$\times$ B. macrocarpa $(23)$ & 4 & 0 \\
\hline$\times$ B. mauiensis $(129)$ & 9 & 0 \\
\hline$\times$ B. molokaiensis $(72)$ & 5 & 0 \\
\hline$\times \# 179 A$ & 8 & 0 \\
\hline B. sandvicensis $(7 \mathrm{~A} \&$ \& 112) $\times$ B. cosmoides $(9)$ & 5 & 0 \\
\hline$\times \# 179 A$ & 4 & 0 \\
\hline$\times$ B. campylotheca $(114)$ & 3 & 0 \\
\hline B. torta $(18) \times B$. mauiensis $(10 \mathrm{~A})$ & 7 & 0 \\
\hline$\# 58 \mathrm{~B} \times \mathrm{B}$. molokaiensis $(72)$ & 2 & 0 \\
\hline$\times$ B. mauiensis $(10 \mathrm{~A})$ & 3 & 0 \\
\hline$\times$ B. valida $(131 \mathrm{~A})$ & 3 & 0 \\
\hline
\end{tabular}

${ }^{*} \mathrm{H}$ : hermaphrodites; MS: male steriles.

\#179A and 179B are F1 hybrids of B. valida $\times$ B. molokaiensis. $58 \mathrm{~B}$ is a natural hybrid of B. torta $\times$ B. amplectens.

crosses made between females and hermaphrodites of gynodioecious species gave either all hermaphrodites or both hermaphrodites and females (table 3 ). In the crosses which gave female progeny, the genotypes of the hermaphrodites used as paternal parents are probably heterozygous for sex-determining genes, since female progeny were repeatedly produced in different crosses when the same hermaphrodite plants were used as pollen donors. A similar segregation pattern is shown in within-species crosses. If the paternal hermaphrodite carries recessive male sterility genes, malesterile progeny will be produced by female plants and segregation will occur when heterozygous hermaphrodites are selfed. This was found in $B$. populifolia plant 42A (table 3).

The number of genes controlling male sterility was investigated by selfing F1 hermaphrodites from the crosses between male steriles and hermaphrodites of non-gynodioecious species shown in table 2 , and also hermaphrodites of gynodioecious species. Table 4 gives the segregation ratios in the F2 generation. In B. hawaiensis, B. forbesii subsp. forbesii, and $B$. populifolia, male sterility appears to be controlled by a single recessive gene, giving $3: 1$ ratios in the $F 2$. However, irregular segregations in the F2 appeared in B. menziesii subsp. filiformis and $B$. sandvicensis subsp. sandvicensis, the ratios are closer to $15: 1$ than to $3: 1$, suggesting a digenic control of male sterility. If male sterility is monogenic recessive, a $1: 1$ ratio should be obtained in the backcross; and if digenic, a 3:1 ratio should be obtained. The results of the backcrosses made for $B$. hawaiensis, B. populifolia, and B. torta are given in Table 5. Regardless of the generally small sample size, the progeny ratios 
Table 3 Segregation in the F1 progenies in experimental crosses between gynodioecious species

\begin{tabular}{|c|c|c|}
\hline \multirow[b]{2}{*}{ Experimental cross } & \multicolumn{2}{|c|}{ No. of F1 progeny } \\
\hline & $\mathrm{H}$ & MS \\
\hline \multirow{2}{*}{\multicolumn{3}{|c|}{$\begin{array}{l}\text { Non-segregating crosses: } \\
\qquad \text { MS ( ) } m m n n \times H() M-N N,(B) m m N N \text { or }\end{array}$}} \\
\hline & & \\
\hline B. cervicata $(8 \mathrm{~B}) \times B$. forbesii $(13 \mathrm{~A})$ & 3 & 0 \\
\hline$\times$ B. sandvicensis $(43 \mathrm{~B})$ & 6 & 0 \\
\hline B. forbesii $(12 \mathrm{~A}) \times B$. menziesii $(31)$ & 10 & $0^{*}$ \\
\hline$\times B$. micrantha $(24 \& 25)$ & 3 & 0 \\
\hline$\times$ B. torta $(39 \mathrm{~A})$ & 6 & 0 \\
\hline B. hawaiensis $(51 \mathrm{~A}) \times B$. forbesii $(71)$ & 2 & 0 \\
\hline B. menziesii $(30 \& 84) \times$ B. amplectens $(1)$ & 5 & 0 \\
\hline B. populifolia $(42 \mathrm{~B}) \times B$. amplectens $(1)$ & 36 & 0 \\
\hline$\times$ B. cervicata $(8 \mathrm{C})$ & 21 & 0 \\
\hline$\times B$. forbesii $(71 \mathrm{~A})$ & 5 & 0 \\
\hline$\times$ B. micrantha $(24 \mathrm{C})$ & 4 & 0 \\
\hline$\times$ B. menziesii $(163 \mathrm{~A})$ & 2 & 0 \\
\hline$\times$ B. sandvicensis $(20 \mathrm{~A})$ & 3 & 0 \\
\hline$\times \# 65 \mathrm{~A}$ & 15 & 0 \\
\hline B. sandvicensis $(7 \mathrm{~A}) \times B$. amplectens $(1)$ & 8 & 0 \\
\hline$\times B$. cervicata $(8 \mathrm{C})$ & 13 & 0 \\
\hline$\times$ B. micrantha $(24 \mathrm{C})$ & 2 & 0 \\
\hline$\times$ B. torta & 3 & 0 \\
\hline \multirow{2}{*}{\multicolumn{3}{|c|}{$\begin{array}{l}\text { Segregating crosses: } \\
\qquad \mathrm{MS}() \mathrm{mmnn} \times \mathrm{H}(\mathrm{)}) \mathrm{Mmnn} \text {. (B) } \mathrm{mmNn} \text { or } \\
\text { ( ) } \mathrm{MmNn}\end{array}$}} \\
\hline & & \\
\hline B. hawaiensis $(51 \mathrm{~A}) \times B$. asymmetrica $(4)$ & 1 & 1 \\
\hline$\times$ B. cervicata $(8 \mathrm{D})$ & 4 & 4 \\
\hline$\times B$. menziesii $(31)$ & 1 & $1^{*}$ \\
\hline$\times$ B. populifolia $(42 \mathrm{~A})$ & 1 & 11 \\
\hline$\times B$. sandvicensis $(112)$ & 15 & 6 \\
\hline B. menziesii $(30 \& 84) \times$ B. sandvicensis $(112)$ & 4 & 2 \\
\hline B. populifolia $(42 B) \times B$. asymmetrica $(4)$ & 3 & 3 \\
\hline$\times$ B. hawaiensis $(52)$ & 2 & 3 \\
\hline$\times$ B. menziesii $(31)$ & 0 & $3^{*}$ \\
\hline B. sandvicensis $(7 \mathrm{~A}) \times B$. menziesii $(31)$ & 0 & $2^{*}$ \\
\hline$\times$ B. asymmetrica $(4)$ & 4 & 2 \\
\hline \multicolumn{3}{|l|}{ Within species: } \\
\hline B. populifolia $(42 B) \times B$. populifolia $(42 \mathrm{C},(\mathrm{A}) \mathrm{MM}--)$ & 12 & 0 \\
\hline (A)mmnn $\times$ B. populifolia $(42 \mathrm{~A},(\mathrm{~A}) \mathrm{Mm}--)$ & 3 & 4 \\
\hline B. populifolia $(42 \mathrm{C})$ self & 5 & 0 \\
\hline B. populifolia (42A) self & 10 & 12 \\
\hline
\end{tabular}

\# 65A is a natural hybrid of $B$. torta $\times$ B. amplectens.

* Genotype of H 31 must be heterozygous according to these results.

are close to $1: 1$ in B. hawaiensis and B. populifolia, in agreement with the $3: 1$ ratio in the F2 for these two species, and the ratio is close to $3: 1$ in $B$. torta, in agreement with 15:1 ratio in the $F 2$ in this species.

The allelism of the male sterility genes in these species was tested by 17 triple-crosses (Table 6) and 4 quadruple crosses (Table 7). In most of the crosses, female progeny were segregated, which is indicative of allelism of male sterility genes in these species. The allelic relationship revealed by segregating crosses in table 3 and by triple-crosses (table 6) and quadruple-crosses (table 7) can be summarised in fig. 2. The ratios of triple crosses in table 6 are either $1: 1$ or $3: 1$, which is in agreement with the backcross ratios of monogenic and digenic recessives respectively. In considering the allelic relationship between female pairs in these 
Table 4 Segregation in F2 progenies

\begin{tabular}{|c|c|c|c|c|c|c|c|}
\hline & \multirow[b]{2}{*}{ Parental cross } & \multicolumn{2}{|c|}{ No. of F2 progeny } & \multirow[b]{2}{*}{$x^{2}(3: 1)$} & \multirow[b]{2}{*}{$p$} & \multirow[b]{2}{*}{$\chi^{2}(15: 1)$} & \multirow[b]{2}{*}{$p$} \\
\hline & & $\mathrm{H}$ & MS & & & & \\
\hline \multicolumn{8}{|c|}{ Crosses with non-gynodioecious species: } \\
\hline (1) & $\begin{array}{l}\text { B. farbesii }(12 \mathrm{~A}) \times \text { B. mauiensis }(10 \mathrm{~B}) \\
(\mathrm{A}) \mathrm{mmnn}\end{array}$ & 72 & 16 & $2 \cdot 182$ & $0 \cdot 20-0 \cdot 10$ & $21 \cdot 382$ & $<0.005$ \\
\hline (2) & $\begin{array}{l}\text { B. hawaiensis }(51 \mathrm{~A}) \times \text { B. mauiensis }(10 \mathrm{~A}) \\
\begin{array}{ll}\text { (A) } \mathrm{mmnn} & \text { (A) } \mathrm{MMNN}\end{array}\end{array}$ & 32 & 12 & $0 \cdot 121$ & $0 \cdot 80-0 \cdot 70$ & $33 \cdot 188$ & $<0.005$ \\
\hline (3) & $\begin{array}{l}\text { B. populifolia }(42 \mathrm{~B}) \times \text { B. mauiensis }(129 \mathrm{~A}) \\
\begin{array}{ll}\text { (A) } \mathrm{mmnn} & \text { (A) MMNN }\end{array}\end{array}$ & 56 & 16 & 0.296 & $0.70-0.50$ & $31 \cdot 348$ & $<0.005$ \\
\hline (4) & $\begin{array}{l}\text { B. menziesii }(30) \times \text { B. mauiensis } \\
\begin{array}{ll}\text { (B) } \mathrm{mmnn} & \text { (A) MMNN }\end{array}\end{array}$ & 16 & 1 & $3 \cdot 313$ & $0.10-0.05$ & 0.004 & 0.95 \\
\hline (5) & $\begin{array}{c}\times \text { B. molokaiensis } \\
(\text { )MMNN }\end{array}$ & 9 & 1 & $1 \cdot 200$ & $0 \cdot 30-0 \cdot 20$ & $0 \cdot 240$ & $0.70-0.50$ \\
\hline (6) & $\begin{array}{l}\text { B. torta }(18) \times \text { B.mauiensis (10A) } \\
\begin{array}{ll}\text { (B) } \mathrm{mmnn} & \text { (A) MMNN }\end{array}\end{array}$ & 26 & 4 & $2 \cdot 178$ & $0 \cdot 20-0 \cdot 10$ & $2 \cdot 569$ & $0 \cdot 20 \cdot 0 \cdot 10$ \\
\hline \multicolumn{8}{|c|}{ Crosses with gynodioecious species: } \\
\hline (7) & $\begin{array}{l}\text { B. menziesii } \times \text { B. hawaiensis } \\
\begin{array}{ll}\text { (B) } \mathrm{mmnn} & \text { (A) } \mathrm{M} \text {-- }\end{array}\end{array}$ & 9 & 3 & 0.000 & $>0.99$ & $7 \cdot 200$ & $<0.01$ \\
\hline$(8)$ & $\begin{array}{l}\times \text { B. sandvicensis } \\
(\mathrm{B}) \mathrm{M}-\mathrm{N}-\end{array}$ & 37 & 4 & $5 \cdot 081$ & $<0.05$ & 0.860 & $0 \cdot 50-0 \cdot 30$ \\
\hline (9) & $\begin{array}{l}\text { B. sandvicensis } \times \text { B. torta } \\
\begin{array}{ll}\text { (B) } \mathrm{mmnn} & \text { ( ) } \mathrm{M}-\mathrm{N}-\end{array}\end{array}$ & 42 & 5 & $5 \cdot 170$ & $<0.05$ & 1.545 & $0 \cdot 30-0 \cdot 20$ \\
\hline \multicolumn{8}{|c|}{ Cross between hermaphrodites: } \\
\hline (10) & $\begin{array}{l}\text { B. mauiensis }(27 \mathrm{C}) \times B \text {. cervicata }(8 \mathrm{D}) \\
(\mathrm{A}) \mathrm{MMNN}\end{array}$ & 9 & 3 & $0 \cdot 000$ & $>0.99$ & $7 \cdot 200$ & $<0.01$ \\
\hline
\end{tabular}

Table 5 Segregation in the progeny of backcross (see Appendix A for species acronym)

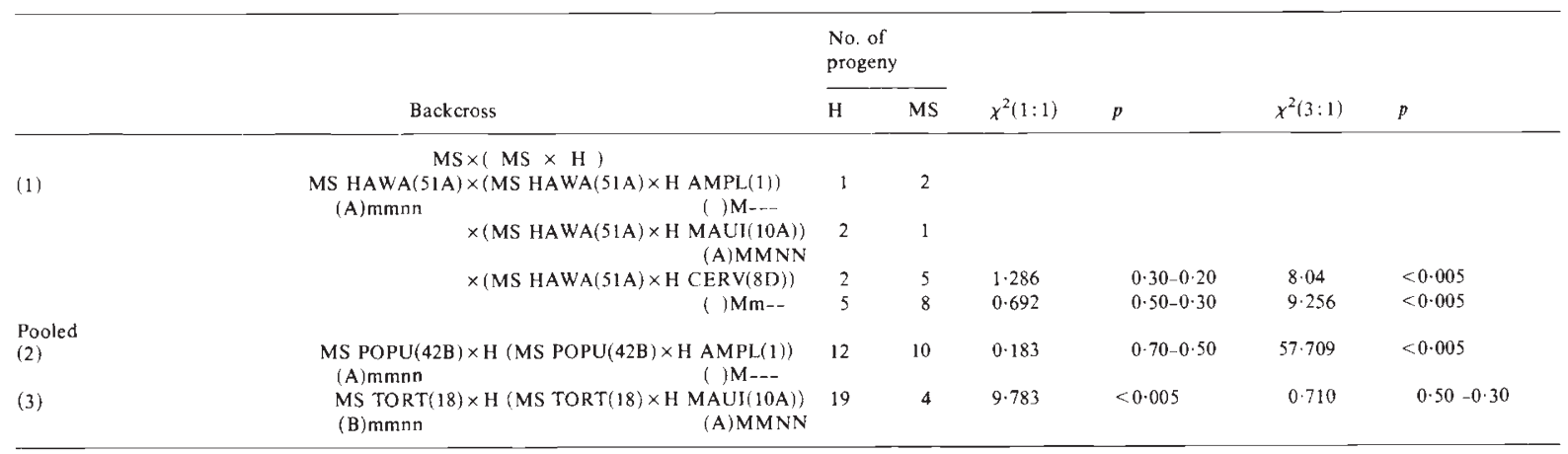

triple crosses, the ratios provide additional support for the monogenic or digenic recessive models. All quadruple-crosses gave $3: 1$ ratios, indicating digenic control of male sterility.

\section{DISCUSSION}

Three general modes of inheritance of male sterility have been proposed for male-sterile mutants in crop plants, and for natural gynodioecious species, i.e., cytoplasmic; genic-cytoplasmic; and genic control of male sterility. Several models of genetic control of male sterility in Hawaiian Bidens can be tested using the results of the experimental crosses.

\section{Cytoplasmic male sterility}

If male sterility were solely controlled by cytoplasm, progenies of females would all be females and progenies of hermaphroditic mothers would be all hermaphrodites. This model can be readily ruled out based on the results presented in tables 1,2 , and 3 .

To choose among the remaining models, the first step is to determine whether nuclear control of male sterility can account for all of the results.

\section{Genic male sterility}

There are several possible nuclear gene models, depending on the dominance relationship and the number of loci involved. 
Table 6 Segregation in triple crosses (see Appendix A for species acronym)

\begin{tabular}{|c|c|c|c|c|c|c|c|}
\hline & \multirow[b]{2}{*}{ Triple cross } & \multicolumn{2}{|c|}{$\begin{array}{l}\text { No. of } \\
\text { progeny }\end{array}$} & \multirow[b]{2}{*}{$\chi^{2}(1: 1)$} & \multirow[b]{2}{*}{$p$} & \multirow[b]{2}{*}{$x^{2}(3: 1)$} & \multirow[b]{2}{*}{$p$} \\
\hline & & $\mathrm{H}$ & MS & & & & \\
\hline \multicolumn{8}{|c|}{$\mathrm{MS} \times(\mathrm{MS} \times \mathrm{H})$} \\
\hline \multirow[t]{2}{*}{ (1) } & $\operatorname{MS~CERV}(88) \times(\operatorname{MS} \operatorname{FORB}(12 \mathrm{~A}) \times \mathrm{H}$ MAUI $(10 \mathrm{~B}))$ & 6 & 0 & $6 \cdot 000$ & $<0.05$ & $2 \cdot 000$ & $0 \cdot 20-0 \cdot 10$ \\
\hline & $\begin{array}{lll}\text { (B) } m m n n & \text { (A) } m m n n & \text { (A) } M M N N\end{array}$ & & & & & & \\
\hline \multirow[t]{2}{*}{ (2) } & $\times(\operatorname{MS}$ MENZ $(30) \times$ H ASYM(4)) & 7 & 2 & $2 \cdot 778$ & $0 \cdot 10-0 \cdot 05$ & 0.037 & $0 \cdot 90-0 \cdot 80$ \\
\hline & (B) $\mathrm{mmnn} \quad$ () $\mathrm{MmN}_{-}$ & & & & & & \\
\hline \multirow{2}{*}{ (3) } & MS FORB $(12 A) \times(\operatorname{MS}$ HAWA $(51 \mathrm{~A}) \times \mathrm{H}$ MAUI $(10 \mathrm{~A}))$ & 25 & 18 & $1 \cdot 140$ & $0 \cdot 30-0 \cdot 20$ & 6.519 & $<0.05$ \\
\hline & $\begin{array}{lll}\text { (A) } m m n n & \text { (A)mmnn } & \text { (A)MMNN }\end{array}$ & & & & & & \\
\hline \multirow[t]{2}{*}{ (4) } & MS MENZ(163) $\times($ MS POPU $(42 B) \times$ H MAUI $(129))$ & 13 & 1 & $10 \cdot 286$ & $<0 \cdot 005$ & $2 \cdot 381$ & $10 \cdot 20-0 \cdot 10$ \\
\hline & $\begin{array}{ll}\text { (B) } m m n n & \text { (A)mmnn }\end{array}$ & & & & & & \\
\hline \multirow[t]{2}{*}{ (5) } & $\times($ MS FORB $(12 A) \times H$ MAUII $(10 B))$ & 8 & 5 & 0.692 & $0 \cdot 50-0 \cdot 30$ & 1.256 & $0 \cdot 30-0 \cdot 25$ \\
\hline & $\begin{array}{ll}\text { (A) } m m n n & \text { (A)MMNN }\end{array}$ & & & & & & \\
\hline \multirow[t]{2}{*}{ (6) } & $\times(\operatorname{MS} \operatorname{MENZ}(30) \times \mathrm{H}$ ASYM(4)) & 2 & 2 & $0 \cdot 000$ & $<0.99$ & $1 \cdot 333$ & $0 \cdot 25-0 \cdot 20$ \\
\hline & (B) $\mathrm{mmnn} \quad$ ( ) $\mathrm{MmN}_{-}$ & & & & & & \\
\hline \multirow[t]{2}{*}{ (7) } & MS MICR (24) $\times(\operatorname{MS}$ POPU $(42 B) \times H$ AMPL(1)) & 9 & 6 & $0 \cdot 600$ & $0 \cdot 50-0 \cdot 30$ & $1 \cdot 800$ & $0 \cdot 20-0 \cdot 10$ \\
\hline & 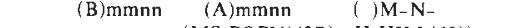 & & & & & & \\
\hline \multirow[t]{2}{*}{$(8)$} & $\times($ MS POPU $(42 B) \times \mathrm{H}$ HILL(68) $)$ & 7 & 0 & $7 \cdot 000$ & $<0.01$ & $2 \cdot 083$ & $0 \cdot 20-0 \cdot 10$ \\
\hline & (A)mmnn ()MMNN & & & & & & \\
\hline \multirow[t]{2}{*}{ (9) } & $\times($ MS HAWA $(51 \mathrm{~A}) \times$ MAUI $(10 \mathrm{~A}))$ & 2 & 3 & $0 \cdot 200$ & $0 \cdot 70-0 \cdot 50$ & $3 \cdot 267$ & $0 \cdot 10-0 \cdot 05$ \\
\hline & (A)mmnn $\quad$ (A)MMNN & & & & & & \\
\hline \multirow[t]{2}{*}{ (10) } & $\operatorname{MS} \operatorname{MICR}(133) \times(\operatorname{MS}$ FORB $(12 A) \times H$ MAUI $(10 B))$ & 18 & 4 & 8.909 & $<0.005$ & 0.545 & $0 \cdot 50-0 \cdot 30$ \\
\hline & $\begin{array}{lll}\text { (B) } m m n n & \text { (A) } m m n n & \text { (A) } M M N N\end{array}$ & & & & & & \\
\hline \multirow[t]{2}{*}{ (11) } & MS SAND $(113) \times($ MS FORB $(12 A) \times$ H MAUI $(10 B))$ & 11 & 3 & 4.571 & $<0.05$ & 0.095 & $0 \cdot 80-0 \cdot 70$ \\
\hline & $\begin{array}{lll}\text { (B) } m m n n & \text { (A) } m m n n & \text { (A) } M M N N\end{array}$ & & & & & & \\
\hline \multirow[t]{2}{*}{ (12) } & $\times(\operatorname{MS} \operatorname{MENZ}(30) \times \mathrm{H} \operatorname{ASYM}(4))$ & 1 & 1 & $0 \cdot 000$ & $>0.99$ & 0.667 & $0 \cdot 50-0 \cdot 30$ \\
\hline & (B) $\mathrm{mmnn} \quad$ () $\mathrm{MmN}_{-}$ & & & & & & \\
\hline \multirow[t]{2}{*}{ (13) } & MS TORT $(19) \times($ MS POPU $(42 B) \times H$ HILL $(68))$ & 2 & 0 & $2 \cdot 000$ & $0 \cdot 20-0 \cdot 10$ & 0.667 & $0 \cdot 50-0 \cdot 30$ \\
\hline & (B)mmnn $\quad$ (A)mmnn & & & & & & \\
\hline \multirow[t]{2}{*}{ (14) } & $\times($ MS HAWA $(51 \mathrm{~A}) \times$ H MAUI $(10 A))$ & 3 & 0 & $3 \cdot 000$ & $0 \cdot 10-0 \cdot 05$ & $1 \cdot 000$ & $0 \cdot 50-0 \cdot 30$ \\
\hline & (A)mmnn $\quad$ (A)MMNN & & & & & & \\
\hline \multirow[t]{2}{*}{ (15) } & $\times(\mathrm{MS}$ POPU $(42 \mathrm{~B}) \times \mathrm{H}$ AMPL(1)) & 1 & 1 & $0 \cdot 000$ & $>0.99$ & 0.667 & $0 \cdot 50-0 \cdot 30$ \\
\hline & (A)mmnn () M-N- & & & & & & \\
\hline \multirow[t]{2}{*}{$(16)$} & MS TORT $(225) \times($ MS FORB $(12 \mathrm{~A}) \times$ H MAUI $(10 \mathrm{~B}))$ & 37 & 27 & $1 \cdot 563$ & $0 \cdot 30-0 \cdot 20$ & $10 \cdot 083$ & $>0.005$ \\
\hline & $\begin{array}{lll}\text { (B) } m m n n & \text { (A)mmnn } & \text { (A) } M M N N\end{array}$ & & & & & & \\
\hline \multirow[t]{2}{*}{$(17)$} & $\times(\operatorname{MS} \operatorname{MENZ}(30) \times \mathrm{H}$ ASYM(4)) & 34 & 26 & $1 \cdot 067$ & $0 \cdot 50-0 \cdot 30$ & $10 \cdot 756$ & $>0.005$ \\
\hline & (B)mmnn $\quad() \mathrm{MmN}-$ & & & & & & \\
\hline
\end{tabular}

Table 7 Segregation in the progeny of quadruple crosses (see Appendix A for species acronym)

\begin{tabular}{|c|c|c|c|c|c|c|c|}
\hline & \multirow[b]{2}{*}{ Quadruple cross } & \multicolumn{2}{|c|}{$\begin{array}{l}\text { No. of } \\
\text { progeny }\end{array}$} & \multirow[b]{2}{*}{$\chi^{2}(1: 1)$} & \multirow[b]{2}{*}{$p$} & \multirow[b]{2}{*}{$\chi^{2}(3: 1)$} & \multirow[b]{2}{*}{$p$} \\
\hline & & $\mathrm{H}$ & MS & & & & \\
\hline (1) & 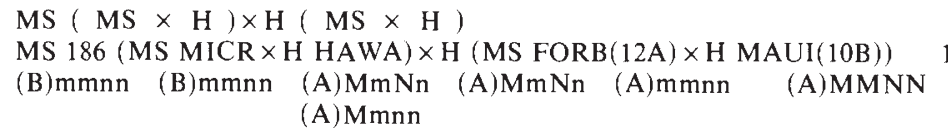 & 16 & 4 & $7 \cdot 200$ & $<0.01$ & 0.267 & $0 \cdot 70-0.50$ \\
\hline (2) & $\begin{array}{l}\times \mathrm{H}(\mathrm{MS} \operatorname{POPU}(42 \mathrm{~B}) \times \mathrm{H} \text { MAUI }(129)) \\
\begin{array}{lll}(\mathrm{A}) \mathrm{MmNn} & \text { (A) } \mathrm{mmnn} & \text { (A)MMNN }\end{array}\end{array}$ & 19 & 5 & $8 \cdot 167$ & $>0.005$ & 0.333 & $0 \cdot 70-0.50$ \\
\hline (3) & 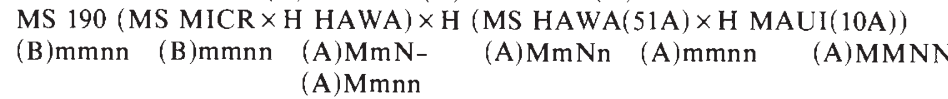 & $\mathrm{IN}^{8}$ & 1 & $5 \cdot 444$ & $<0.05$ & 0.926 & $0.50-0.30$ \\
\hline (4) & $\begin{array}{l}\times \mathrm{H}(\mathrm{MS} \mathrm{MENZ}(30) \times \mathrm{H} \text { MAUI }) \\
\begin{array}{lll}(\text { B) } \mathrm{MmNn} & \text { (B) } \mathrm{mmnn} & \text { (A) } \mathrm{MMNN}\end{array}\end{array}$ & 15 & 4 & $6 \cdot 368$ & $<0.05$ & $0 \cdot 158$ & $0.70-0.50$ \\
\hline
\end{tabular}

\section{Male sterility dominant}

If male sterility is caused by a single dominant nuclear gene $M$, females can have only the genotype $\mathrm{Mm}$, while hermaphrodites can have only the genotype $\mathrm{mm}$. The segregation ratios $(\mathrm{H}: \mathrm{MS})$ should always be $1: 1$ in the progenies of females, and 1:0 in the progenies of maternal hermaphrodites. With two or more dominant loci, regardless of gene interaction, progenies of females should always contain females. This model can be readily eliminated based on the data in tables 1,2 , and 3 (progenies of females that were all hermaphrodites). 


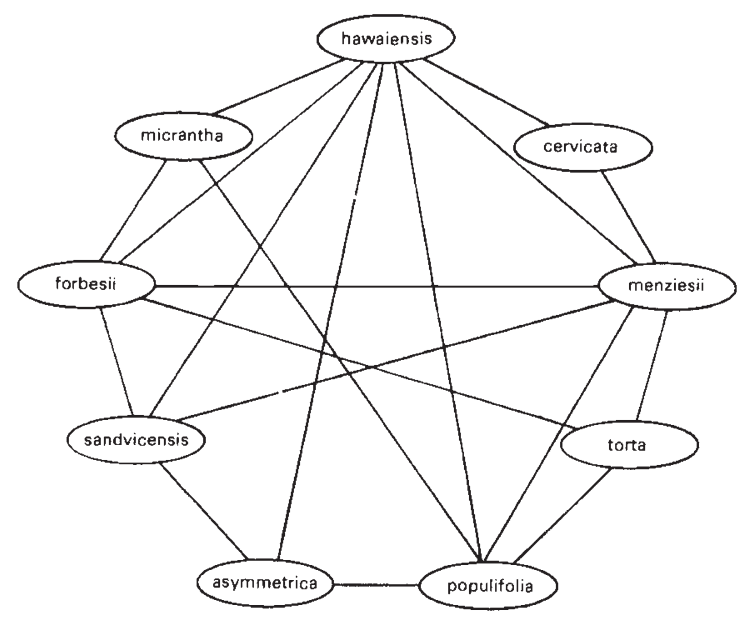

Figure 2 Allelism for male sterility in nine species of Hawaiian Bidens demonstrated by interspecific crosses.

\section{Male sterility recessive}

One locus model If male sterility is caused by a single recessive nuclear gene, $\mathrm{mm}$ will be the only genotype for females, and $\mathrm{MM}$ or $\mathrm{Mm}$ for hermaphrodites. This model can account for all the results in the $F 1$ (tables, 2, 3), and the 3:1 F2 ratios and $1: 1$ backcross ratios obtained for $B$. forbesii, $B$. hawaiensis and B. populifolia (tables 4,5 ), but cannot explain the $15: 1 \mathrm{~F} 2$ ratios in $B$. menziesii and $B$. sandvicensis (Crosses 8, 9 in table 4), or the $3: 1$ ratio in the backcross of $B$. torta (Cross 3 in table 5). Nor can this model account for the $3: 1$ ratio in triple crosses (Crosses $1,4,8,10,11$ in table 6) or the quadruple crosses (table 7).

Two locus model If male sterility is determined by two duplicate recessive genes $m$ and $n$, females will have only the genotype, $m m n n$, while all other genotypes are hermaphrodites. $F 1$ ratios can be $1: 0,1: 1$, or $3: 1$ and $F 2$ ratios can be $15: 1$ or $3: 1$, depending on the genotypes of parental hermaphrodites. This model can explain all the results in F1 progenies (table 2,3), but cannot explain the F2 ratios in crosses $1,2,3$ in table 4 if all individuals of the hermaphroditic species $B$. mauiensis have the same genotype MMNN. If assuming that hermaphroditic species were fixed with the genotypes either $\mathrm{MM}--$ or --NN, the $3: 1$ ratios in crosses 1, 2, 3 and 4 (table 4) could be explained. Under this assumption, however, no consistent genotype can be assigned to the individual, $\mathrm{H} 10 \mathrm{~A}$, of $B$. mauiensis in the crosses 2 and 6 (table 4). In the F2 progenies of cross 6, $26 \mathrm{H}: 4 \mathrm{MS}$ were segregated, the ratio fit for both $3: 1$ and $15: 1$ with close probability. The backcross 3 (table 5) gave a $3: 1$ ratio, in agreement with the $15: 1$ ratio in the $F 2$. Thus the only genotype which can be assigned to H $10 A$ is MMNN, whereas it has to be MMnn or mmNN in Cross 2. Nor can a consistent genotype be assigned to $\mathrm{H} 10 \mathrm{~B}$ in considering the $\mathrm{F} 2$ ratio in Cross 1 (Table 4) and discordant ratios in triple crosses $1,10,11,16$ (table 6) and in the quadruple cross 1 (table 7). Thus, this model cannot sufficiently explain the data of this study.

Another two locus model, in which either locus causes male sterility when homozygous recessive, would give a $9: 7$ ratio in the F2. None of the experimental crosses gave the $9: 7$ ratio in the $F 2$. This model can be readily ruled out.

\section{Two locus epistatic model}

This model has been previously proposed for the gynodioecious species Origanum vulgare (Lewis and Crowe, 1956) and Cortaderia spp. (Connor, 1973). In this system, the dominant gene $F$ causes male sterility and a dominant fertility-restoring gene $\mathrm{H}$ is epistatic to $\mathrm{F}$, thus females can only have genotypes FFhh or Ffhh, whereas hermaphrodites can be any of the rest of the genotypes: FFHH, FFHh, FfHH, FfHh, ffHH, ffHh and ffhh. Crosses between females and hermaphrodites can give $F 1$ ratios $1: 0,1: 1,5: 3,3: 1$, or $0: 1 ; \mathrm{F} 2$ ratios $3: 1$, $13: 3$, or $1: 0$; and the backcross ratios $1: 1,3: 1$, or $5: 3$. The diagnostic ratios useful in distinguishing this model from the others are $0: 1$ in $F 1,13: 3$ and $1: 0$ in F2, and $5: 3$ in the backcross. For a small sample size, the $5: 3$ ratio is hardly distinguishable from a $1: 1$ ratio. Although the $13: 3$ ratio has a higher probability than either $3: 1$ or $15: 1$ ratio in cross 1 and 6 (table 4 ), the $0: 1$ ratio in $F 1$ and 1:0 ratio in F2 were never found for any crosses with a sample size $n>3$. Crosses 3 (table 5), 6 (table 4) and 1, 4, and 10 (table 6) have too many hermaphrodites in the progenies compared to the expected $1: 1$ or $5: 3$ ratios. These ratios are expected because the individuals of $B$. mauiensisis must be homozygous dominant at the $\mathrm{H}$ locus to always give hermaphrodite progenies in the F1 (table 2). So this model is also unlikely.

\section{Genic-cytoplasmic model}

All experimental crosses suggest that either one or two recessive genes control male sterility. However, crosses of the same hermaphrodite plant to females of different species gave different results, showing that there must be genetic differences among females as well. This result does not appear to be explainable by any strictly nuclear model for the inheritance of male sterility. 
However, if male sterility is controlled by interactions between cytoplasm and nuclear genes, the differences between females can be accounted for by cytoplasmic differences between species or populations. This model postulates that there are two types of cytoplasm (A) and (B), and two nuclear genes, $m$ and $n$. In cytoplasm (A), homozygous recessives at the $m$ locus are male sterile, regardless of the genotype at the $n$ locus. In cytoplasm (B), both the $m$ and $n$ loci must be homozygous recessive for male sterility to be expressed. Therefore, depending on the cytoplasm, male sterility can appear to be controlled by either one or two recessive nuclear genes.

$$
\begin{array}{cl}
\text { Cytoplasm } & \text { Female genotype } \\
\text { A } & \mathrm{mmN} \text { - or mmnn } \\
\text { B } & \mathrm{mmnn}
\end{array}
$$

With (A) cytoplasm, only the $m$ locus affects male sterility, so that the F2 from a double heterozygote gives a $3: 1$ phenotypic ratio

$$
\begin{aligned}
& 9 \text { (A)M-N- : } 3 \text { (A)mmN- : } 3 \text { (A)M-nn : } 1 \text { (A)mmnn } \\
& \begin{array}{llll}
\mathrm{H} & \mathrm{MS} & \mathrm{H} & \mathrm{MS}
\end{array}
\end{aligned}
$$

Whereas in cytoplasm (B), both dominant fertilityrestoring genes function, giving a 15:1 ratio in the F2.

$$
\begin{aligned}
& 9 \text { (B)M-N- : } 3 \text { (B)mmN- : 3 (B) M-nn : } 1 \text { (B)mmnn } \\
& \begin{array}{llll}
\mathrm{H} & \mathrm{H} & \mathrm{H} & \mathrm{MS}
\end{array}
\end{aligned}
$$

This model requires no difference, at least at $\mathrm{m}$ locus, in the nuclear genotypes of females in different gynodioecious species. This is consistent with developmental data, which suggested a uniform mechanism of male sterility in Hawaiian Bidens (Sun, 1986). It also agrees with the allelic nature of male sterility genes among these species (fig. 2). This model alone appears to be able to account for all data in this study. Genotypes were thus assigned, based on this model, to all individuals for all crosses presented in the tables.

Cytoplasmic male sterility appears to readily evolve, as suggested by numerous reports on cytoplasmic and genic-cytoplasmic male sterility in crop plants (see Edwardson, 1970, and Laser and Lerstern, 1972 for reviews). However, simple cytoplasmic male sterility is rare in naturally occurring gynodioecious species. So is simple nuclear genic male sterility, although genic male sterile mutants have also been frequently reported for crop plants (Jain, 1959). In almost all well studied species, gynodioecy appears to be controlled by the interaction between cytoplasmic factors and nuclear genes (see Ross, 1978, and Charlesworth, 1981 for reviews).
The inheritance of male sterility in Origanum vulgare was first proposed as digenic and epistatic (Lewis and Crowe, 1956), as discussed above. Recent studies of this species by Kheyr-Pour (1980, 1981), however, revealed a complicated cytoplasmic-genic system of male sterility. Ross (1969) proposed a digenic recessive mechanism of male sterility in Plantago lanceolata, but two or more types of mechanisms were recently reported for this species, each showing complicated geniccytoplasmic nature (Van Damme and Van Delden, 1982; Van Damme, 1983). The basic genetic mechanism for male sterility in Thymus vulgaris is also genic-cytoplasmic (Valdeyron et al., 1977). Gynodioecy in Limnanthes douglasii was initially interpreted as monogenic dominant inheritance (Jain et al., 1978), but a later study of the species gave results suggesting that male sterility appeared to be genic-cytoplasmic (Kesseli and Jain, 1984). Evidence for cytoplasmic inheritance with nuclear restorer genes is shown in Nemophila menziesii (Ganders, 1978).

Lack of simple cytoplasmic or simple genic male sterility in natural gynodioecious species may result from their evolutionary instability. Simple nuclear genic male sterility can readily evolve to dioecy through gradual accumulation of completely linked recessive genes for male sterility and of dominant or nondominant genes for partial female sterility (Ross and Weir, 1975; Ross, 1978). Mutations reducing female fertility of hermaphrodites appear to be a common occurrence (Ross, 1978; Charlesworth, 1981). Simple cytoplasmic male sterility is rare because restorer mutations can convert cytoplasmic inheritance of male sterility into cytoplasmic-genic inheritance (Charlesworth, 1981). In contrast, genic-cytoplasmic male sterility appears to be evolutionarily stable because linkage can hardly occur between nuclear partial female sterility and cytoplasmic male sterility (Ross, 1978).

All Hawaiian species of Bidens evolved from a single ancestral species after long-distance dispersal (Gillett, 1975; Ganders and Nagata, 1983, 1984; Marchant et al., 984; Helenurum and Ganders, 1985), but only about half of them are gynodioecious. Gynodioecy is not known in species of Bidens outside the Hawaiian Islands. Gynodioecy in Hawaiian Bidens, therefore, most likely evolved autochthonously. Male-sterile mutants are at a selective disadvantage because they transmit genomes to the next generation only through ovules, whereas hermaphrodites transmit genomes through both ovules and pollen and through the ovules of male-sterile mutants. However, male ster- 
ility can evolve to gynodioecy under favorable conditions (Lewis, 1941; Lloyd, 1974, 1975; Sun, 1986; Sun and Ganders, 1986). Although male sterility might be controlled by different genetic mechanisms in different gynodioecious species, the homogeneous phenotypic and developmental expression of male sterility suggests a homologous origin of male sterility (Sun, 1986; Sun and Ganders, 1987). Directly allelic relationship among male sterility genes in different species (fig. 2) provides further evidence that male sterility mutation event occurred only once in Hawaiian Bidens. The 13 currently known gynodioecious taxa are most likely the products of adaptive radiation of one ancestral gynodioecious species, in which the original male sterility mutation event occurred. The differentiation of cytoplasm in the gynodioecious line could evolve later. Natural hybridization could also spread male sterility genes into hermaphroditic populations, since all species are interfertile (Ganders and Nagata, 1983). I conclude that male sterility in all gynodiecious species of Hawaiian Bidens is controlled by the same genetic mechanism. Among the possible mechanisms, genic-cytoplasmic inheritance is the only one which explains the results of all experimental crosses in this study. This model can be further tested by reciprocal crosses between species with presumably different cytoplasm.

Acknowlegement I thank Drs K. Cole, F. R. Ganders, A. J. F. Griffiths, S. K. Jain and J. Myers for critical reading of the early manuscript. I also thank Bob Kantymir for greenhouse assistance. This paper is a portion of a Ph.D. dissertation submitted to the University of British Columbia in partial fulfilment of the requirements for the Doctor of Philosophy degree.

\section{REFERENCES}

CHARLESWORTH, D. 1981. A further study of the problem of the maintenance of females in gynodioecious species. Heredity, 46, 27-39.

CONNOR, H. E. 1973. Breeding systems in Cortaderia (Gramineae). Evolution, 27, 663-678.

EDWARDSON, J. R. 1970. Cytoplasmic male sterility. Bot. Rev., 36, 341-420.

GANDERS, F. R. 1978. The genetics and evolution of gynodioecy in Nemophila menziesii. Can. J. Bot., 56, 1400-1408.

GANDERS, F. R., AND NAGATA, K. M. 1983. Relationships and floral biology of Bidens cosmoides. Lyonia, 2, 23-31.
GANDERS, F. R. AND NAGATA, K. M. 1984. The role of hybridization in the evolution of Bidens on the Hawaiian islands. In Grant W. F. (ed.) Plant Biosystematics, Academic Press Canada, Don Mills, Ontario, pp. 179-194.

GILleTt, G. W. 1975. The diversity and history of Polynesian Bidens, Sect. Campylotheca. Harold. L. Lyon. Arboretum Lecture, 6, 1-32.

GOTTSCHALK. W. AND KAUL, M. L. H. 1974. The genetic control of microsporogenesis in higher plants. Nucleus (Calcutta), 17, 133-166.

HELENURM, K. AND GANDERS, F. R. 1985. Adaptive radiation and genetic differentiation in Hawaiian Bidens. Evolution, 39, 753-765.

JAIN, S. K. 1959. Male-sterility in flowering plants. Bibl. Genet., $18,101-166$.

JAIN, S. K., BOUSSY, I. A. AND HAUPTLI, H. 1978. Male sterility in meadowfoam. J. Hered., 69, 61-63.

KESSELI, R. AND JAIN, S. K. 1984. An ecological genetic study of gynodioecy in Limnanthes douglasii. Amer. J. Bot., 71, 775-786.

KHEYR-POUR, A. 1980. Nucleo-cytoplasmic polymorphism for male sterility in Origanum vulgare L. J. Hered., 71, 253-260.

KHEYR-POUR, A. 1981. Wide nucleo-cytoplasmic polymorphism for male sterility in Origanum vulgare L. J. Hered., 72, 45-52.

LASER, K. D. AND LERSTEN, N. R. 1972. Anatomy and cytology of microsporogenesis in cytoplamic male sterile angiosperms. Bot. Rev., 38, 425-454.

LEWIS, D. 1941. Male-sterility in natural populations of hermaphrodite plants. New Phytol., 40, 56-63.

LEWIS, D. AND CROWE, L. K. 1956. The genetics and evolution of gynodioecy. Evolution, 10, 115-125.

LLOYD, D. G. 1974. Theoretical sex ratios of dioecious and gynodioecious angiosperms. Heredity, 32, 11-34.

LLOYD, D. G. 1975. The maintenance of gynodioecy and androdioecy in angiosperms. Genetica, 45, 325-339.

MARCHANT, Y. Y., GANDERS, F. R., WAT, C.-K. AND TOWERS, G. H. N. 1984. Polyacetylenes in Hawaiian Bidens (Asteraceae). Biochem. Syst. Ecol., 12, 167-178.

Ross, M. D. 1969. Digenic inheritance of male sterility in Plantago lanceolata. Can. J. Genet. Cytol., 11, 739-744.

ROSS, M. D. 1978. The evolution of gynodioecy and subdioecy. Evolution, 32, 174-188.

ROSS, M. D. AND WEIR, B. S. 1975. Maintenance of male sterility in plant populations III. Mixed selfing and random mating. Heredity, 35, 21-29.

SUN, M. 1986. Mixed mating systems and gynodioecy in Hawaiian Bidens. Ph.D. Thesis, Univ. of British Columbia, Vancouver.

ṠUN, M. AND GANDERS, F. R. 1986. Female frequencies in gynodioecious populations correlated with selfing rates in hermaphrodites. Amer. J. Bot., 73, 1645-1648.

SUN, M. AND GANDERS, F. R. 1987. Microsporogenesis in male-sterile and hermaphroditic plants of nine gynodioecious taxa of Hawaiian Bidens. Amer. J. Bot., 74, 209-217.

VALdeYRon, G., DOMMEe, B. AND VERNET, P. 1977. Selffertilization in male-fertile plants of a gynodioecious species: Thymus vulgaris L. Heredity, 39, 243-249.

VAN DAMME, J. M. M. 1983. Gynodioecy in Plantago lanceolata L. II. Inheritance of three male sterility types. Heredity, 50, 253-273.

VAN DAMME, J. M. M., AND VAN DELDEN, w. 1982. Gynodioecy in Plantago lanceolata L. I. Polymorphism for plasmon type. Heredity, 49, 303-318. 
Appendix A Native Hawaiian taxa of Bidens. Taxa known to be gynodioecious are preceded by an asterisk

\begin{tabular}{|c|c|c|}
\hline Taxon & $\begin{array}{l}\text { Species } \\
\text { acronym }\end{array}$ & Distribution \\
\hline $\begin{array}{l}\text { B. amplectens Sherff } \\
\text { B. asymmetrica (H. Lev.) Sherff } \\
\text { B. campylotheca Schz. Bip. ssp. campylotheca } \\
\text { B. campylotheca ssp. pentamera (Sheriff) Ganders \& Nagata } \\
\text { B. campylotheca ssp. waihoiensis St. John } \\
\text { B. cervicata Sherff } \\
\text { B. conjuncta Sherff } \\
\text { B. cosmoides (A. Gray) Sherff } \\
\text { B. forbesii Sherff ssp. forbesii } \\
\text { * B. forbesii ssp. kahiliensis Ganders \& Nagata } \\
\text { *. hawaiensis A. Gray } \\
\text { B. hillebrandiana (Drake) Deg. ex Sherff ssp. hillebrandiana } \\
\text { B. hillebrandiana ssp. polycephala Nagata and Ganders } \\
\text { B. macrocapa (A. Gray) Sherff } \\
\text { B. mauiensis (A. Gray) } \\
\text { B. menziesii (A. Gray) Sherff ssp menziesii } \\
\text { *. menziesii ssp. filiformis (Sherff) Ganders \& Nagata } \\
\text { B. micrantha Gaud. ssp. micrantha } \\
\text { B. micrantha ssp. ctenophylla (Sherff) Nagata \& Ganders } \\
\text { B. micrantha ssp. kalealaha Nagata \& Ganders } \\
\text { B. molokaiensis (Hillebr.) Sherff } \\
\text { B. populifolia Sherff } \\
\text { * Bandvicensis Less. ssp. sandvicensis } \\
\text { B. sandvicensis ssp. confusa Nagata \& Ganders } \\
\text { B. torta Sherff } \\
\text { B. valida Sherff } \\
\text { B. wiebkei Sherff }\end{array}$ & $\begin{array}{l}\text { FORB } \\
\text { FORB } \\
\text { HAWA } \\
\text { HILL } \\
\text { HILL } \\
\text { MAUI } \\
\text { MENZ } \\
\text { MENZ } \\
\text { MICR } \\
\text { MICR } \\
\text { MOLO } \\
\text { POPU } \\
\text { SAND } \\
\text { SAND } \\
\text { TORT }\end{array}$ & $\begin{array}{l}\text { Oahu } \\
\text { Oahu } \\
\text { Hawaii, Lanai, Oahu } \\
\text { Maui } \\
\text { Maui } \\
\text { Kauai, Oahu, Niihau } \\
\text { Maui } \\
\text { Kauai } \\
\text { Kauai } \\
\text { Kauai } \\
\text { Hawaii } \\
\text { Hawaii } \\
\text { Maui, Molokai } \\
\text { Oahu } \\
\text { Lanai, Maui } \\
\text { Maui, Molokai } \\
\text { Hawaii } \\
\text { Maui } \\
\text { Hawaii } \\
\text { Lanai, Maui } \\
\text { Molokai, Oahu } \\
\text { Oahu } \\
\text { Kauai, Oahu } \\
\text { Kauai } \\
\text { Oahu } \\
\text { Kauai } \\
\text { Molokai }\end{array}$ \\
\hline
\end{tabular}

